\title{
Trans- $\varepsilon$-Viniferin Encapsulation in Multi-Lamellar Liposomes: Consequences on Pharmacokinetic Parameters, Biodistribution and Glucuronide Formation in Rats
}

\author{
Pauline Beaumont ${ }^{1}$, Chrystel Faure ${ }^{2}$, Arnaud Courtois ${ }^{1,3} \mathbb{D}^{\mathbb{D}}$, Michael Jourdes ${ }^{1} \mathbb{D}$, Axel Marchal ${ }^{1} \mathbb{D}$, \\ Pierre-Louis Teissedre ${ }^{1} \mathbb{D}$, Tristan Richard ${ }^{1} \mathbb{D}$, Claude Atgié $^{2, *}$ and Stéphanie Krisa ${ }^{1, *(\mathbb{D})}$
}

1 INRAE, Bordeaux INP, UR OENOLOGIE, EA 4577, USC 1366, ISVV, Université de Bordeaux, 33140 Villenave d'Ornon, France; pauline.beaumont@u-bordeaux.fr (P.B.); arnaud.courtois@u-bordeaux.fr (A.C.); michael.jourdes@u-bordeaux.fr (M.J.); axel.marchal@u-bordeaux.fr (A.M.); pierre-louis.teissedre@u-bordeaux.fr (P.-L.T.); tristan.richard@u-bordeaux.fr (T.R.)

2 CNRS, Bordeaux INP, CBMN, UMR 5248, Université de Bordeaux, 33600 Pessac, France; chrystel.faure@enscbp.fr

3 Centre Antipoison et de Toxicovigilance de Nouvelle Aquitaine, Bâtiment UNDR, CHU de Bordeaux, Place Amélie Raba Léon, 33076 Bordeaux, France

* Correspondence: claude.atgie@enscbp.fr (C.A.); stephanie.krisa@u-bordeaux.fr (S.K.); Tel.: +33-(0)5-40-00-68-37 (C.A.); +33-(0)5-57-57-59-53 (S.K.)

Citation: Beaumont, P.; Faure, C.; Courtois, A.; Jourdes, M.; Marchal, A.; Teissedre, P.-L.; Richard, T.; Atgié, C.; Krisa, S. Trans- $\varepsilon$-Viniferin Encapsulation in Multi-Lamellar Liposomes: Consequences on Pharmacokinetic Parameters, Biodistribution and Glucuronide Formation in Rats. Nutrients 2021, 13, 4212. https://doi.org/10.3390/ nu13124212

Academic Editors: Itziar Eseberri, Leixuri Aguirre and Susanne Klaus

Received: 12 October 2021

Accepted: 23 November 2021

Published: 24 November 2021

Publisher's Note: MDPI stays neutral with regard to jurisdictional claims in published maps and institutional affiliations.

Copyright: (c) 2021 by the authors. Licensee MDPI, Basel, Switzerland. This article is an open access article distributed under the terms and conditions of the Creative Commons Attribution (CC BY) license (https:// creativecommons.org/licenses/by/ $4.0 /)$.
Abstract: Trans- $\varepsilon$-viniferin $(\varepsilon$ Vin) is a resveratrol dimer exhibiting promising biological activities for human health. Its bioavailability being low, the development of encapsulation methods would be used to overcome this issue. The aim of this study was to measure the consequences of the encapsulation of $\varepsilon$ Vin in multilamellar liposomes on its pharmacokinetic parameters, metabolism and tissue distribution in rats. After oral administration of $\varepsilon$ Vin $(20 \mathrm{mg} / \mathrm{kg}$ body weight), either as free or encapsulated forms, plasmas were sequentially collected (from 0 to $4 \mathrm{~h}$ ) as well as liver, kidneys and adipose tissues ( $4 \mathrm{~h}$ after administration) and analyzed by LC-HRMS. The glucuronide metabolites $(\varepsilon V G)$ were also produced by hemisynthesis for their quantification in plasma and tissues. The encapsulation process did not significantly modify the pharmacokinetic parameters of $\varepsilon$ Vin itself. However, a significant increase of the $\mathrm{T}_{1 / 2}$ was noticed for $\varepsilon V G$ after administration of the encapsulated form as compared to the free form. An accumulation of $\varepsilon$ Vin and $\varepsilon V G$ in adipose tissues was noticed, and interestingly a significant increase of the latter in the mesenteric one after administration of the encapsulated form was highlighted. Since adipose tissues could represent storage depots, and encapsulation allows for prolonging the exposure time of glucuronide metabolites in the organism, this could be of interest to promote their potential biological activities.

Keywords: Trans- $\varepsilon$-viniferin; resveratrol dimer; pharmacokinetic; liposome encapsulation; biodistribution

\section{Introduction}

Trans- $\varepsilon$-viniferin ( $\varepsilon$ Vin) is a resveratrol dehydrodimer belonging to the stilbene's family. Stilbenes are phytoalexins present in several edible plant families [1]. The main source of these compounds in European food is grapes [2] and their derivative products such as grapes juice or wine, but also peanuts and red fruits $[3,4]$. The average daily consumption of stilbenes differs according to several criteria but is estimated at $0.5 \mathrm{mg} /$ person/day according to a Spanish study, and $0.3 \mathrm{mg} /$ person/day according to a Chinese one $[3,5,6]$.

Although resveratrol is the most widely studied stilbene for its biological activities, recent research focuses on the biological properties of other stilbenes. Indeed, numerous studies on the biological properties of $\varepsilon$ Vin, a dimer present in red wines [7] in the wood of Vitis vinifera (up to $7.7 \mathrm{~g} / \mathrm{kg}$ dry weight, more abundant than resveratrol [8]), have shown that this molecule could have some benefits for human health. 
$\varepsilon$ Vin has indeed shown antioxidant activities, by inhibiting the radical $\mathrm{ABTS}^{\bullet+}[9,10]$ and also by inhibiting peroxidation of $\beta$-carotene, or by limiting oxidation of $\mathrm{DMSO} / \mathrm{O}_{2}-$ system [11]. $\varepsilon$ Vin also reduced nitric oxide production by microglia and macrophages (BV-2 cells and RAW 264.7 cells) activated by lipopolysaccharide, suggesting some antiinflammatory properties [12,13]. Moreover, studies have shown interesting $\varepsilon$ Vin neuroprotective activities, by inhibiting A $\beta$ aggregation involved in Alzheimer's disease [14,15], or by activating sirtuin 3 and protecting mitochondrial functions in a huntingtin mutant cell line [16]. Experiments on cancer cell lines like those derived from hepatocytes, fibroblasts, and leukemia cells or lymphoids revealed antiproliferative activities of $\varepsilon$ Vin [17-22], even if other studies suggested no or very low activity [23,24]. Other research groups have shown more efficient in vitro anti-hepatitis $C$ virus [25], antidepressant [26], and cardioprotective activities by decreasing the systolic blood pressure in spontaneously hypertensive rats by comparing to its monomer resveratrol $[27,28]$. Moreover, $\varepsilon$ Vin is also promising for its anti-adipogenic properties insofar as it has been shown that this compound decreased lipid accumulation and adipogenesis marker gene expression such as Peroxisome Proliferatoractivated Receptor gamma (PPARY) in a 3T3-L1 adipocytes cell line [29]. The decrease in body weight gain in rat fed with a high fat diet and the reduction of the mass of white adipose tissues in mice after oral administration of $\varepsilon$ Vin $[29,30]$ highlight its potential in vivo biological activities. These interesting properties lead to asking the question of its fate in the systemic circulation after ingestion.

Nowadays, and to our knowledge, the only study about $\varepsilon$ Vin pharmacokinetic characterization and bioavailability after oral administration was published by Kim et al. [31]. They showed a $\varepsilon$ Vin maximal concentration $\left(C_{\max }\right)$ of $42 \mathrm{ng} / \mathrm{mL}$ for a maximal time ( $\mathrm{T}_{\max }$, time to reach the $\mathrm{C}_{\max }$ ) between 15 and $30 \mathrm{~min}$ after oral administration of $40 \mathrm{mg} / \mathrm{kg}$ body weight (bw) in mice, and calculated a bioavailability of $0.77 \%$ [31]. This very poor bioavailability could be explained by a low absorption through the intestinal barrier [32] and/or a strong intestinal and/or liver metabolism. It is now well documented that stilbenes are indeed subjected to biotransformations such as sulfation and glucuronidation, via sulfotransferase and UDP-glucuronosyltransferase, respectively. These detoxification processes take place mainly in the liver but also to a significant level in the enterocytes of the small intestine. These enzymatic transformations result in an increase of the compound hydrophilicity for an easier elimination into bile and urine. Two recent studies from our laboratory clearly confirmed a high metabolism of $\varepsilon$ Vin in vitro (S9 liver extract) and in vivo (in rats). In this last in vivo study, the pharmacokinetic parameters calculated, after intraperitoneal injection in rats, a $C_{\max }$ at 3.09,5.16 and $0.2 \mu \mathrm{g} / \mathrm{mL}$ for $\varepsilon V$ in, its glucuronide $(\varepsilon V G)$ and its sulfate $(\varepsilon V S)$ metabolites, respectively, for an equivalent $\mathrm{T}_{\max }$ at $1 \mathrm{~h}$ [33]. However, it is noteworthy that, in these previous studies, the concentrations of these metabolites were expressed as the equivalent of the native form, as $\varepsilon V G$ and $\varepsilon V S$ are not commercially available. Metabolism was also observed for an isomer of $\varepsilon$ Vin, $\delta$-viniferin, after an oral administration at $70 \mathrm{mg} / \mathrm{kg}$ bw in rats. Indeed, Mao et al. quantified the glucuronides of $\delta$-viniferin, after hydrolysis with glucuronidase, and measured a concentration of glucuronide metabolites up to 7-fold higher than the native form [34]. Finally, the quantification of $\varepsilon$ Vin and its metabolites in adipose tissue after intraperitoneal administration showed an accumulation of the molecule mainly in its native form, suggesting a storage role for this tissue [33].

Due to the very poor bioavailability of stilbenes, developing innovative formulations like micro-encapsulation could be a solution to improve their bioavailability [35]. Several methods have been proposed to increase the stability, solubility and bioavailability of polyphenols [36-38] such as single and double emulsions, co-crystallization, encapsulation in yeasts and liposomes. Some studies on polyphenols encapsulation (such as resveratrol, curcumin and quercetin) have shown a real efficiency in improving their pharmacokinetic parameters and their bioavailability [39], by increasing $C_{\max }$ or $T_{1 / 2}$ [40-43].

Liposomes are good candidates for in vivo applications because of their biocompatibility and low toxicity. The lipid bilayers that constitute liposomes allow for protecting 
polyphenols against UV irradiation and cis-trans isomerization [44,45], increasing their stability and preserving their anti-oxidant properties [46]. Among the different types of liposome encapsulation, multi-lamellar liposomes (MLLs) are advantageous for the encapsulation of polyphenols because of the presence of several bilayers in which lipophilic molecules, such as $\varepsilon$ Vin, are inserted [47], leading to a higher encapsulation rate. Oniontype MLLs, also called spherulites $\odot$, are made up of lipid bilayers up to the core of vesicles, contrary to classical MLLs that display a limited number of bilayers and a large water core. Recently, we produced $\varepsilon$ Vin-loaded onions displaying a high encapsulation rate [48], considerably increasing its water solubility, and showing a decreased cytotoxicity of encapsulated $\varepsilon$ Vin on Caco-2 cell line [45].

This study aimed to investigate the consequences of $\varepsilon$ Vin encapsulation in onion-type MLLs on its pharmacokinetic parameters and tissular distribution after oral administration in rats. Plasma and tissue concentrations of the native form ( $\varepsilon$ Vin) will be assessed, as well as those of glucuronides, through hemisynthetic production of these metabolites.

\section{Materials and Methods}

2.1. Chemical and Stock Solutions

\subsubsection{Chemical and Reagents}

$\varepsilon$ Vin was produced as previously described [49], by extraction from grape shoot powder batch, and purity was confirmed by ${ }^{1} \mathrm{H}$ NMR (>89\%). P75 (soya bean lecithin with $68-74 \%$ phosphatidylcholine and $7-11 \%$ phosphatidylethanolamine) was purchased from Lipoid $\mathrm{GmbH}$ (Ludwigshafen, Germany). Tween 80, $\mathrm{K}_{2} \mathrm{CO}_{3}$, acetobromo-glucuronic acid methyl-ester, pyridine chlorosulfonic acid and propylene glycol were purchased from Sigma-Aldrich (Saint Quentin Fallavier, France). Methanol, ethanol and acetonitrile (LCMS)-grade, trifluoroacetic acid (TFA) and formic acid were purchased from Fisher Scientific (Loughborough, UK), and ultra-pure water was produced using Purelab Ultra System (Elga Lab Water, High Wycombe, UK).

\subsubsection{Metabolites Production}

The four glucuronides (Figure 1) were obtained by hemisynthesis as previously described [50] with some modifications. One molar equivalent $\varepsilon$ Vin was dissolved in ethanol and then mixed with 20 molar equivalents of $\mathrm{K}_{2} \mathrm{CO}_{3}$. Six molar equivalents of acetobromoglucuronic acid methyl-ester dissolved in ethanol were added, and the reaction mixture was stirred at $50{ }^{\circ} \mathrm{C}$ for $24 \mathrm{~h}$ under agitation. The reaction was then stopped by lowering the $\mathrm{pH}$ below 5 with $1 \%$ formic acid. Solvents were evaporated with a vacuum rotatory evaporator before redissolving sample in methanol:water (50:50, v:v). The mixture was injected into semi-preparative high-performance liquid chromatography equipped with a binary pump and UV-VIS detector used at $320 \mathrm{~nm}$ (Prostar 325, Varian, Palo Alto, CA, USA). Solvents A and B were ultra-pure water and acetonitrile:water (50:50, v:v), respectively, both acidified with $0.025 \%$ of TFA. The gradient, used with a $2 \mathrm{~mL} / \mathrm{min}$ flow rate, was as follows: $0 \mathrm{~min}, 38 \% \mathrm{~B}$; 0-55 min, 38-48\% B; 55-57 min, 48-100\% B; 57-60 min, 100\% B; 60-62 $\mathrm{min}, 100-38 \% \mathrm{~B} ; 62-64 \mathrm{~min} ; 38 \% \mathrm{~B}$. Metabolites were individually collected and then injected in UPLC-DAD-MS to ensure their purity before being freeze-dried. For method validation and a calibration curve, V2G (Figure 1) was used as it is the most predominant isomer found in rats [33].

\subsubsection{Stock Solutions and Calibration Curves}

$\varepsilon$ Vin and V2G were precisely weighed and dissolved in ultra-pure (HPLC)-grade methanol to obtain a $1 \mathrm{mg} / \mathrm{mL}$ concentration. Stock solutions were aliquoted and stored at $-20^{\circ} \mathrm{C}$ until use. For calibration curves, dilutions were applied to give the following concentrations in methanol:water (50:50, v:v): 0.5, 1, 2.5, 5, 10, 25, 50, 100 and $250 \mathrm{ng} / \mathrm{mL}$ and $25,50,100,250,500,1000,2500 \mathrm{ng} / \mathrm{mL}$ for $\varepsilon$ Vin and V2G, respectively. 
(a)

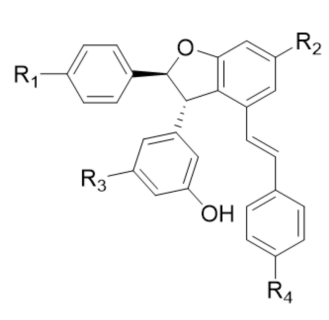

(b)

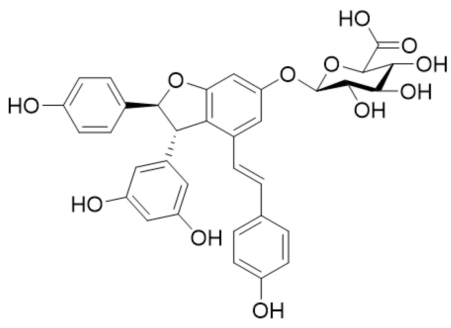

(c)

\begin{tabular}{ccccc}
\hline Compound & R1 & R2 & R3 & R4 \\
\hline \&Vin & OH & OH & OH & OH \\
V1G & Gluc & OH & OH & OH \\
V2G & OH & Gluc & OH & OH \\
V3G & OH & OH & Gluc & OH \\
V4G & OH & OH & OH & Gluc \\
\hline
\end{tabular}

Figure 1. Structure of the 4 isomers of $\varepsilon$ Vin. (a) basic structure; (b) structure of V2G; (c) location of glucuronide group (gluc) depending on the isomer.

\subsection{EVin-Loaded MLLs}

\subsubsection{Preparation of Onions-Type MLLs}

MLLs were produced as previously described $[33,48]$. Briefly, P75, Tween 80 and $\varepsilon \operatorname{Vin}(52.5 \mathrm{wt} \%, 11.5 \mathrm{wt} \%$ and $4 \mathrm{wt} \%$ of the final composition, respectively) were first individually solubilized in ethanol before being mixed together. The organic solvent was then removed by evaporation under $\mathrm{N}_{2}$ flux $(0.1 \mathrm{bar})$. The mixture was freeze-dried $(48 \mathrm{~h})$ and precisely weighed. The first half of ultra-pure water required (16 wt $\%$ ) was added. Shearing using a microspatula was performed $(1 \mathrm{~min})$ before adding the other half of water $(16 \mathrm{wt} \%)$ and starting three cycles of shear stress. One shear stress cycle consisted of $5 \mathrm{~min}$ of shearing with the spatula and $5 \mathrm{~min}$ of centrifugation $(2000 \mathrm{rpm})$. The resulting viscous phase, made of MLLs in close contact, was kept at $4{ }^{\circ} \mathrm{C}$ for $24 \mathrm{~h}$, and three additional shear stress cycles were then operated.

In Vivo experiments on rats were performed using encapsulated $\varepsilon$ Vin. To remove un-encapsulated $\varepsilon$ Vin, MLLs were suspended in ultra-pure water $(20 \mathrm{mg} / \mathrm{mL}, 40 \mathrm{~mL}$ per tube). An initial centrifugation (10 min, $500 \mathrm{rpm}$ ) allowed the precipitation of potential $\varepsilon$ Vin aggregates. The supernatants were then ultra-centrifuged for three hours at $100,000 \times g$ and $8{ }^{\circ} \mathrm{C}$ (fast acceleration, slow deceleration), and supernatants were removed to keep only $\varepsilon$ Vin encapsulated in MLLs.

\subsubsection{Characterization}

The multi-lamellar character of the liposomes was confirmed by polarized light microscopy (Olympus BX51, ×60 and ×100 magnifications, Hamburg, Germany). The encapsulation rate of $\varepsilon$ Vin in MLLs was determined using UV-Vis spectrophotometry and using an adsorption filtration method as previously developed [48]. The liposomes distribution size was established using dynamic light scattering (DLS, Vasco particle size analyzer, Cordouan Technologies Ltd., Pessac, France) with a refractive index of 1.33 and 1.45 for water and liposomes, respectively. The measurement was done in triplicate and results were analyzed using the Cumulant method. Finally, the zeta potential was determined using ZetaSizer Nano Series (Malvern Instrument Ltd., Worcestershire, UK).

\subsection{Pharmacokinetic Studies}

\subsubsection{Animals and Treatments}

Experiments were conducted in accordance with Directive 2010/63/EU [51] and approved by the Bordeaux University Institutional Ethics Committee for Animal Research (IEC-AR CEEA 50, MESR approval A18380). Male Wistar rats (Janvier-LABS, Saint Berthevin, France) were maintained in controlled conditions: $12 \mathrm{~h}$ light/12 h dark cycle, humidity $50-60 \%$ and an ambient temperature of $24 \pm 1{ }^{\circ} \mathrm{C}$ (animal facility agreement number: B33-063-917). Free access to food and water was allowed up to $16 \mathrm{~h}$ before experiments started. Rats were randomly divided into two groups. Group A $(n=5$, average weight $=307.8 \pm 7.7 \mathrm{~g})$ received $\varepsilon$ Vin dissolved in propylene glycol $(5.25 \mathrm{mg} / \mathrm{mL})$, while group B $(n=6$, average weight $=308 \pm 10.7 \mathrm{~g})$ received the same dose of $\varepsilon$ Vin but encap- 
sulated in MLLs and suspended in ultra-pure water. Both solutions were administrated by oral gavage and precisely measured to reach a dose of $20 \mathrm{mg} / \mathrm{kg}$ bw of $\varepsilon$ Vin. Blood was collected through the tail vein, making a slanting incision during the first collection. Rats were slightly anesthetized by isoflurane before every blood sample collection $(600 \mu \mathrm{L})$ at the following time points: 20, 40, 60, 100, 140, 180 and $210 \mathrm{~min}$ after gavage. They were sacrificed at $240 \mathrm{~min}$ by a high dose of isoflurane and rapid exsanguination with saline solution injected in the right ventricular cardiac cavity with a peristaltic pump $(10 \mathrm{~mL} / \mathrm{min})$. All blood samples were collected in heparinized tubes and centrifuged $(10,000 \times g, 10 \mathrm{~min})$ before sampling plasma. The liver, kidneys and four white adipose tissues (epididymal, retroperitoneal, mesenteric and subcutaneous) were removed, weighed and immediately immersed in liquid nitrogen. All blood and tissues samples were kept at $-80{ }^{\circ} \mathrm{C}$ until analysis.

\subsubsection{Extraction of $\varepsilon$ Vin and Metabolites from Plasma and Tissues}

Extractions were performed as previously described [33] with some modifications to improve quantification. For plasma extraction, $360 \mu \mathrm{L}$ of methanol $\left(4^{\circ} \mathrm{C}\right)$ were added to an aliquot of $120 \mu \mathrm{L}$ of plasma. The sample was vortexed during three minutes before centrifugation ( $30 \mathrm{~min}, 12,000 \times g, 4^{\circ} \mathrm{C}$ ). The supernatant $(380 \mu \mathrm{L})$ was removed and evaporated using a SpeedVac concentrator (Labconco CentriVap, Thermo Fisher Scientific, Waltham, MA, USA). Residue was kept in $-80{ }^{\circ} \mathrm{C}$ before analysis. For tissues extraction, tissues (about $0.5 \mathrm{~g}$ ) were first cut with scalpels before being mixed with $4 \mathrm{~mL}$ of methanol:water $(80: 20, v: v)$. Samples were homogenized with an Ultra-Turrax homogenizer (IKA, Staufen, Deutschland) before being intensely vortexed. Then, samples were centrifuged $20 \mathrm{~min}$ at $10,000 \times g$ and $4{ }^{\circ} \mathrm{C}$ before sampling $3 \mathrm{~mL}$ of supernatant. All supernatants were evaporated using a SpeedVac concentrator and kept at $-80{ }^{\circ} \mathrm{C}$. Residues were reconstituted in $60 \mu \mathrm{L}$ and $250 \mu \mathrm{L}$ of methanol:water (50:50, v:v) or plasma and tissue, respectively. They were vortexed intensely and centrifuged at $12,000 \times g$ during $30 \mathrm{~min}$ at $4{ }^{\circ} \mathrm{C}$ before being injected the supernatant in LC-HRMS.

\subsection{LC-HRMS Quantification}

The quantification of $\varepsilon$ Vin and the total of glucuronides $(\varepsilon V G)$ in plasma and tissues was performed as previously described [33] with some modifications concerning the mass parameters. The U-HPLC separation was carried out with a Vanquish Flex system (Thermo Fisher Scientific, Les Ulis, France) consisting in a binary pump, an autosampler and a heated column compartment. The liquid chromatography separation was performed as previously detailed using C18 column (BEH C18 $2.1 \mathrm{~mm} \times 100 \mathrm{~mm}, 1.7 \mu \mathrm{m}$ particle size, Waters, Guyancourt, France). The flow rate was set as $450 \mu \mathrm{L} / \mathrm{min}$. The injection volume was $5 \mu \mathrm{L}$ and the eluents were $0.1 \%$ formic acid in water for $\mathrm{A}$ and $0.1 \%$ formic acid in acetonitrile for B. The eluent B varied as follows: $0 \mathrm{~min}, 25 \%$; $0.5 \mathrm{~min}, 25 \%$; $3.6 \mathrm{~min}, 50 \% ; 3.9 \mathrm{~min}, 50 \%$; $4 \mathrm{~min}, 100 \%$; $5.7 \mathrm{~min}, 100 \%$; $5.8 \mathrm{~min}, 25 \%$; $7 \mathrm{~min}, 25 \%$. The column and sample temperature were $30{ }^{\circ} \mathrm{C}$ and $20^{\circ} \mathrm{C}$, respectively. The Exactive benchtrop Orbitrap mass spectrometer equipped with a HESI probe (both from Thermo Fisher Scientific, Bremen, Germany) was used. The source parameters were optimized as follows: sheath gas flow rate 65 arbitrary units (a.u.); auxiliary gas flow rate 15 a.u.; sweep gas flow rate 3 a.u.; spray voltage $-3.5 \mathrm{kV}$; capillary temperature $350^{\circ} \mathrm{C}$; capillary voltage $-60 \mathrm{~V}$; tube lens voltage $-135 \mathrm{~V}$; skimmer voltage $-26 \mathrm{~V}$ and HESI probe temperature $320^{\circ} \mathrm{C}$. Full MS scan data were acquired in negative ion mode within the range of $m / z 100-1800$ at a resolution of 25,000 FWHM. The automatic gain control target was set at $1 \mathrm{e} 6$ ions, with a maximum injection time of $100 \mathrm{~ms}$. Data generated from XCalibur (version 2.1, Thermo Fisher Scientific, Waltham, MA, USA) with Qualbrowser and Quanbrowser, and area under curves (AUC) were determined by integrating peaks obtained from extracted ion chromatograms built in a 5-ppm window around the theoretical mass of the deprotonated ions [M-H]- (at $m / z 453.1343 \mathrm{u}$ and $m / z$ 629.1664 for $\varepsilon$ Vin and $\varepsilon V G$, respectively). 


\subsection{Method Validation}

The method validation was carried out in accordance with the United States Food and Drug Administration [52] and the European Medicines Agency Guidelines [53] as previously described in other pharmacokinetic studies [54-59].

\subsubsection{Calibration Curves and Limit of Quantification (LOQ)}

The LOQ of $\varepsilon$ Vin and V2G were determined by injecting each concentration 5 times and calculating the relative standard deviation (RSD). LOQs were defined as the lowest concentrations for which trueness (deviation from nominal value) and precision (RSD) were less than $15 \%$. The calibration curve of each compound was determined by integrating peak areas from appropriated extracted ion chromatogram. Each calibration curve was done by spiking the analytes in extracted blank plasma. The correlation coefficient $\left(R^{2}\right)$ ensured good linearity $(>0.9)$.

\subsubsection{Selectivity, Carry-Over, Intra-Day Precision and Accuracy}

Each sample was realized in triplicate. Blank plasmas spiked with $\varepsilon$ Vin or V2G at the highest concentrations were directly injected before blank solvent to perform a carry-over test. To ensure a good selectivity, blank plasmas were also injected after solvent spiked with $\varepsilon$ Vin or V2G. For both tests, peaks at the same retention time of compounds were integrated. An area under curve (AUC) of non-spiked blank plasma and blank solvent inferior to $20 \%$ of LOQ ensured an acceptable selectivity and carry-over, respectively.

An intra-day test was performed by spiking low concentration $(2.5 \mathrm{ng} / \mathrm{mL}$ for $\varepsilon$ Vin and $25 \mathrm{ng} / \mathrm{mL}$ for V2G, LC), medium concentration $(25 \mathrm{ng} / \mathrm{mL}$ for $\varepsilon$ Vin and $250 \mathrm{ng} / \mathrm{mL}$ for V2G, MC) and high concentration ( $250 \mathrm{ng} / \mathrm{mL}$ for $\varepsilon$ Vin and $2500 \mathrm{ng} / \mathrm{mL}$ for V2G, HC) in solvent (methanol:water, 50:50, v:v) and in five replicates. RSD (\%) and relative error (RE, \%) from the nominal value were calculated to determine precision and accuracy, respectively.

\subsubsection{Matrix Effect (ME) and Extraction Recovery (ER)}

LC, MC and HC were spiked in extracted blank plasma in five replicates. Each concentration was also prepared in solvent (methanol:water, 50:50, v:v) in five replicates. After integrating each peak in the extracted ion chromatogram, ME was calculated as follows:

$$
\mathrm{ME}=\frac{\text { AUC analyte spiked in blank plasma after extraction }}{\text { AUC analyte in solvent }} * 100
$$

For ER, blank plasmas were spiked with $4 \mu \mathrm{L}$ of three concentrations prepared in ultra-pure water before operating the extraction protocol. Concentrations were calculated in order to obtain final concentration of LC, MC and HC after extractions, each in five replicates. Fifteen other samples were prepared spiking with the same concentrations in solvent (three concentrations, 5 replicates). After integrating each peak in the extracted ion chromatogram, ER was calculated as follows:

$$
\mathrm{ER}=\frac{\text { AUC analyte spiked in blank plasma before extraction }}{\text { AUC analyte in solvent }} * 100
$$

\subsection{Data Analysis}

Mean concentration-time profiles of $\varepsilon$ Vin and $\varepsilon V G$ in the rats at scheduled sampling times were analyzed with the non-compartmental pharmacokinetic method using PKSolver (an Excel add-on), and maximum concentration $\left(C_{\max }\right)$ and time to reach $C_{\max }\left(T_{\max }\right)$ were recorded directly. Significant differences of $\varepsilon$ Vin and $\varepsilon V G$ concentrations in tissues and plasmas were determined using a Student's $t$-test. 


\section{Results}

\subsection{EVin-Loaded MLL Characterization}

The encapsulation of $\varepsilon$ Vin was carried out by following the optimized protocol developed previously [48]. The multi-lamellar character was checked by polarized light microscopy. Indeed, the organized structure of MLLs induces birefringence that produces Maltese crosses, as previously observed [48]. Their average size was $247 \pm 8 \mathrm{~nm}$ as measured by DLS, while their Zeta potential was $-47.0 \pm 0.4 \mathrm{mV}$, in accordance with previous results $[45,48]$. The encapsulation efficiency was $75 \pm 5 \%$. After separating the free $\varepsilon \operatorname{Vin}$ from the encapsulated one by ultra-centrifugation (see Section 2.2.1), the pellets were analyzed in UPLC-MS to administer a precise quantity of $\varepsilon$ Vin to the animals.

\subsection{Validation of Extraction and LC-HRMS Quantitation Method}

The extraction and the analytical method for the quantification of $\varepsilon$ Vin and V2G in plasma were validated using five replicates in terms of sensitivity, selectivity, carry-over, intraday precision, accuracy, matrix effect and extraction recovery.

The correlation coefficient of the calibration curves $\left(R^{2}=0.999\right.$ for $\varepsilon$ Vin and V2G) ensured a good linearity. LOQ was determined at $0.5 \mathrm{ng} / \mathrm{mL}$ for $\varepsilon$ Vin and $25 \mathrm{ng} / \mathrm{mL}$ for V2G. No significant peak was measured at the retention times of the compounds, which ensured acceptable selectivity (data not shown). Blank plasmas injected after plasmas spiked with HC did not contain $\varepsilon$ Vin or its glucuronide forms, which validated the carryover test (data not shown). For the intraday precision and accuracy tests, RSD (\%) and RE $(\%)$ were calculated respectively, from blank plasmas spiked with LC, MC or HC $(n=5)$. For the three tested concentrations, both precision and accuracy were less than $15 \%$ for $\varepsilon$ Vin, and only RE was higher than $15 \%$ for V2G in low concentrations (Table 1 ).

Table 1. Intraday precision of $\varepsilon$ Vin and V2G in rat plasma $(n=5)$.

\begin{tabular}{cccccc}
\hline \multirow{2}{*}{$\varepsilon \operatorname{Lin}$} & Level & $\begin{array}{c}\text { Spiked Concentration } \\
(\mathbf{n g} / \mathbf{m L})\end{array}$ & $\begin{array}{c}\text { Mean Concentration } \\
(\mathbf{n g} / \mathbf{m L})\end{array}$ & $\begin{array}{c}\text { RSD } \\
\mathbf{( \% )}\end{array}$ & $\begin{array}{c}\text { RE } \\
\mathbf{( \% )}\end{array}$ \\
\cline { 2 - 6 } & LC & 2.5 & $2.5 \pm 0.2$ & 9.1 & 0.8 \\
\cline { 2 - 6 } & MC & 25 & $23.4 \pm 0.4$ & 1.6 & -6.4 \\
\hline \multirow{2}{*}{ V2G } & HC & 250 & $249.6 \pm 4.6$ & 1.8 & -0.2 \\
\cline { 2 - 6 } & LC & 25 & $33.9 \pm 0.7$ & 2.1 & 35.6 \\
\cline { 2 - 6 } & MC & 250 & $236.1 \pm 3.3$ & 1.4 & -5.5 \\
\hline
\end{tabular}

Results for matrix effect and extraction recovery are shown in Table 2. For $\varepsilon$ Vin, the matrix effect was considered negligible. On the other hand, we can note a slight decrease in peak intensity for the extraction recovery measurement. For V2G, there was no impact of the extraction process on metabolite signal but a significant matrix effect with a signal loss of about $30 \%$. The establishment of the standard curves directly in the matrix allows us to free ourselves from this ME.

\subsection{Pharmacokinetic Study}

The evolution of the plasma concentrations over time of $\varepsilon$ Vin (expressed in $\mathrm{pmol} / \mathrm{mL}$ of $\varepsilon$ Vin) and the total glucuronide metabolites (expressed in $\mathrm{pmol} / \mathrm{mL}$ of V2G, the main metabolite) are shown in Figure 2. The main pharmacokinetic parameters are detailed in the inserts of Figure 2 and in Table 3. 
Table 2. Matrix effect and extraction recovery of $\varepsilon$ Vin and V2G in rat plasma.

\begin{tabular}{|c|c|c|c|c|c|c|}
\hline & \multirow[b]{2}{*}{ Level } & \multirow[b]{2}{*}{$\begin{array}{l}\text { Spiked Concentration } \\
(\mathrm{ng} / \mathrm{mL})\end{array}$} & \multicolumn{2}{|c|}{ Matrix Effect } & \multicolumn{2}{|c|}{ Extraction Recovery } \\
\hline & & & $\begin{array}{c}\text { Mean } \pm \text { SD } \\
(\%)\end{array}$ & $\begin{array}{c}\text { RSD } \\
(\%)\end{array}$ & $\begin{array}{c}\text { Mean } \pm \text { SD } \\
(\%)\end{array}$ & $\begin{array}{c}\text { RSD } \\
(\%)\end{array}$ \\
\hline \multirow{3}{*}{$\varepsilon \operatorname{Vin}$} & LC & 2.5 & $93.3 \pm 7.2$ & 7.8 & $87.2 \pm 30.1$ & 34.5 \\
\hline & $\mathrm{MC}$ & 25 & $115.1 \pm 2.3$ & 2.0 & $87.2 \pm 3.8$ & 4.4 \\
\hline & $\mathrm{HC}$ & 250 & $103.7 \pm 4.4$ & 4.2 & $74.7 \pm 1.4$ & 7.8 \\
\hline \multirow{3}{*}{$\mathrm{V} 2 \mathrm{G}$} & LC & 25 & $70.5 \pm 15.2$ & 21.5 & $114.7 \pm 14.4$ & 12.6 \\
\hline & $\mathrm{MC}$ & 250 & $69.2 \pm 4.5$ & 6.5 & $96.2 \pm 7.8$ & 8.1 \\
\hline & $\mathrm{HC}$ & 2500 & $69.5 \pm 4.2$ & 6.1 & $96.8 \pm 4.2$ & 4.3 \\
\hline
\end{tabular}
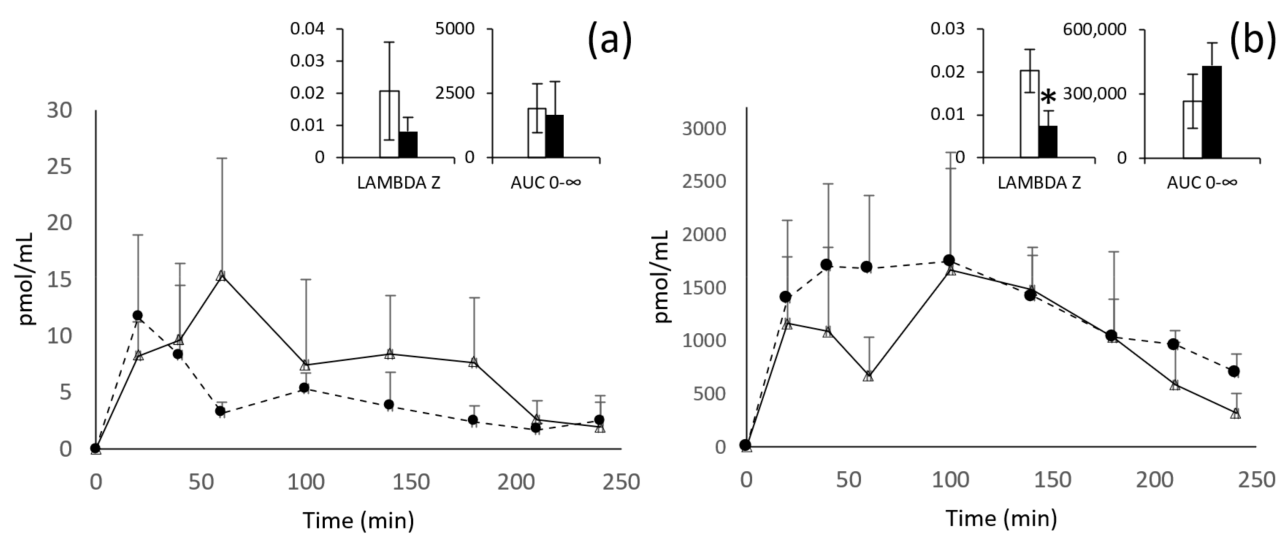

Figure 2. Kinetic profiles of $\varepsilon \operatorname{Vin}(\mathbf{a})$ and $\varepsilon V G(\mathbf{b})$ after oral administration of $20 \mathrm{mg} / \mathrm{kg}$ bw of free (white triangles) or encapsulated (black circles) $\varepsilon$ Vin. Data are expressed in $\mathrm{pmol} / \mathrm{mL}$ of plasma + standard deviation (SD). Lambda $\mathrm{z}$ and $\mathrm{AUC}_{0-\infty}$ are expressed in $\mathrm{min}^{-1}$ and $\mathrm{pmol} / \mathrm{mL} / \mathrm{min}$, respectively. Comparisons between free (white) or encapsulated (black) forms administration were analyzed by Student's $t$-test $\left({ }^{*} p<0.05\right)$.

Table 3. Pharmacokinetic parameters of $\varepsilon$ Vin and $\varepsilon V G$ in rat plasma after oral administration of free or encapsulated form. $\mathrm{T}_{\max }, \mathrm{T}_{1 / 2}$ and mean residence time (MRT) were expressed in minutes, $\mathrm{C}_{\max }$ in $\mathrm{pmol} / \mathrm{mL}$, AUC in $\mathrm{pmol} / \mathrm{mL} / \mathrm{min}$ and Lambda $\mathrm{z}$ in $\mathrm{min}^{-1}$. Comparisons between encapsulated or free form administration were analyzed by Student's $t$-test $\left({ }^{*} p<0.05\right)$.

\begin{tabular}{ccccc}
\hline & & EVin & & EVG \\
\cline { 2 - 5 } & Free & Encapsulated & Free & Encapsulated \\
\hline $\mathrm{T}_{\max }$ & 60 & 20 & 100 & 100 \\
\hline $\mathrm{C}_{\max }$ & $15.3 \pm 10.5$ & $11.7 \pm 7.3$ & $1667.4 \pm 1103.3$ & $1746.3 \pm 875.6$ \\
\hline $\mathrm{T}_{\frac{1}{2}}$ & $55.0 \pm 33.9$ & $114.8 \pm 80.4$ & $38.2 \pm 11.2$ & $118.8 \pm 65.1 *$ \\
\hline $\mathrm{AUC}_{0-\mathrm{t}}$ & $1689.1 \pm 682.0$ & $1009.8 \pm 328.3$ & $245,827.3 \pm 114,219.8$ & $307,086.4 \pm 316,383.9$ \\
\hline $\mathrm{AUC}_{0-\infty}$ & $1919.7 \pm 955.2$ & $1660.1 \pm 1313.1$ & $264,191.0 \pm 123,786.4$ & $432,315.4 \pm 106,406.4$ \\
\hline MRT & $126.9 \pm 27.9$ & $196.4 \pm 130.4$ & $123.7 \pm 12.0$ & $213.2774 \pm 93.9$ \\
\hline Lambda z & $0.0207 \pm 0.0153$ & $0.0082 \pm 0.0043$ & $0.0198 \pm 0.0056$ & $0.0074 \pm 0.0036^{*}$ \\
\hline
\end{tabular}

After oral administration of the free form of $\varepsilon$ Vin $20 \mathrm{mg} / \mathrm{kg}$ bw, the plasma concentration of the untransformed form reached its maximum concentration after one hour $\left(C_{\max }=15 \pm 11 \mathrm{pmol} / \mathrm{mL}\right)$. The total glucuronides reached their $C_{\max }$ after $100 \mathrm{~min}$ and 
have a concentration 108 times higher than the aglycone form. For these glucuronides, two peaks of concentration are clearly visible at 20 and $100 \mathrm{~min}$ (Figure 2b).

Considering the encapsulation of $\varepsilon$ Vin in MLLs, despite apparent difference in the plasma kinetic profiles, no significant effect was observed in all the pharmacokinetic parameters followed for the original form ( $\varepsilon$ Vin). However, after administration of the encapsulated form of $\varepsilon$ Vin, glucuronides are also the predominant form present in plasma. Moreover, encapsulation of $\varepsilon$ Vin modifies the kinetics of $\varepsilon V G$. Indeed, a plateau is observed from $20 \mathrm{~min}$ to $100 \mathrm{~min}$, instead of the two peaks obtained with free $\varepsilon$ Vin. Moreover, the time required for the elimination of $50 \%\left(\mathrm{~T}_{1 / 2}\right)$ of the glucuronide metabolites is significantly increased, nearly 3 times (from $38 \pm 11$ min to $119 \pm 65, p<0.05$ ) by the encapsulation procedure, in accordance with a significant decrease of the late elimination constant (Lambda $\mathrm{z}$ ) in the same range of magnitude (from $0.0198 \pm 0.0056 \mathrm{~min}^{-1}$ to $0.0074 \pm 0.0036 \mathrm{~min}^{-1}$, $p<0.05)$ and a tendency to increase in $\mathrm{AUC}_{0-\infty}$ (Table 3, Figure $2 \mathrm{~b}$ insert).

\subsection{Quantification in Tissue}

The $\varepsilon$ Vin biodistribution displays great differences in terms of concentration but also of native/glucuronide form ratio according to the tissues (Figure 3).

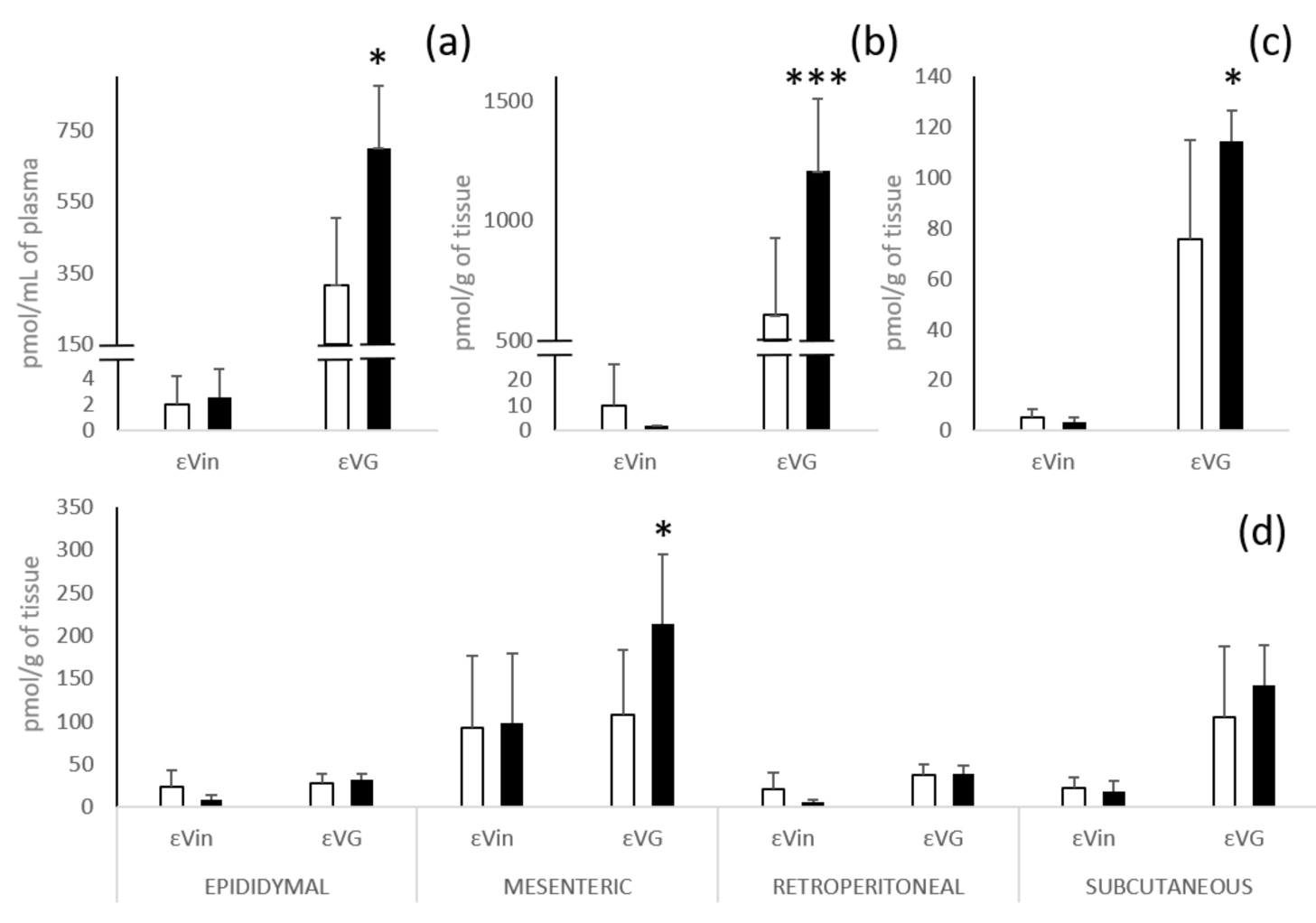

Figure 3. Quantification of $\varepsilon$ Vin and $\varepsilon V G$ in plasma (a); liver (b); kidneys (c); and different white adipose tissues (d) $4 \mathrm{~h}$ after oral administration of $20 \mathrm{mg} / \mathrm{kg}$ bw of $\varepsilon$ Vin in free (white bars) or encapsulated (black bars) forms. Bars represent concentrations expressed at $\mathrm{pmol} / \mathrm{mL}$ for plasma and $\mathrm{pmol} / \mathrm{g}$ of tissue for tissue $+\mathrm{SD}$. Comparisons between encapsulated or free form administration were analyzed by Student's $t$-test $\left({ }^{*} p<0.05 ; * * *<0.0005\right)$.

After administration of the free form of $\varepsilon$ Vin, total glucuronides are the majority forms in plasma, liver, and kidneys. In liver and kidneys, $\varepsilon$ Vin does not exceed a concentration of $10 \mathrm{pmol} / \mathrm{g}$, while $\varepsilon V G$ reached $604 \pm 320$ and $76 \pm 39 \mathrm{pmol} / \mathrm{g}$ of tissue, respectively (60 times and 14 times the concentration of the native molecule) (Figure $3 b, c$ ). These marked higher contents of $\varepsilon V G$ in plasma, liver and kidneys are not observed in adipose tissues (Figure 3d). The highest concentration of the native form was found in mesenteric adipose tissue $(92 \pm 84 \mathrm{pmol} / \mathrm{g}$ of tissue versus concentrations around $20 \mathrm{pmol} / \mathrm{g}$ of tissue for the three other depots). For the glucuronides form, only subcutaneous adipose tissue 
had a much higher $\varepsilon$ VG concentration than $\varepsilon$ Vin (105 \pm 83 versus $23 \pm 12 \mathrm{pmol} / \mathrm{g}$ of tissue). Four hours after administration, the concentrations of $\varepsilon$ Vin in all the adipose tissues are always largely higher (5 to 10 times) than those measured in the other tissues (liver and kidneys) and plasmas.

The administration of the same amount of $\varepsilon$ Vin, in an encapsulated form, significantly increased (nearly double) the concentration of $\varepsilon V G$ in plasma (317 \pm 186 to $700 \pm 175 \mathrm{pmol} / \mathrm{mL}$ ), liver (604 \pm 320 to $1206 \pm 304 \mathrm{pmol} / \mathrm{g}$ of tissue), kidneys (76 \pm 39 to $114 \pm 12 \mathrm{pmol} / \mathrm{g}$ of tissue) and also in the mesenteric adipose tissue (108 $\pm 75 \mathrm{pmol} / \mathrm{g}$ to $213 \pm 81 \mathrm{pmol} / \mathrm{g}$ of tissue) (Figure 3). This effect was not observed for the native form.

Independently of the administration form of $\varepsilon \mathrm{Vin}$, it was observed that the levels of $\varepsilon V$ in and $\varepsilon V G$ were markedly higher (2 to 3 times) in mesenteric adipose tissue than in the three other adipose tissues, except for the level of $\varepsilon V G$ in the subcutaneous depot. Finally, it looked like encapsulation led to a slight decrease in the concentration of native form after administration of MLLs in epididymal and retroperitoneal tissues.

\section{Discussion}

This study was carried out with the aim to specifically quantify a resveratrol dimer, $\varepsilon$-viniferin and its main metabolites, namely the mono-glucuronide forms, in biological samples after oral administration of this stilbene with or without an encapsulation procedure.

Trans- $\varepsilon$-viniferin-glucuronide production allowed its specific quantification in rat plasmas and tissues. In this study, we used one isomer of glucuronide where the glucuronide moiety is linked to the thirteenth carbon of the molecule (V2G, Figure 1). V2G, which is the major isomer found in vitro after incubation with hepatic fractions [50] and in vivo after intraperitoneal injection of $\varepsilon$ Vin in rat [33], is also the main glucuronides isomers formed of this study for both administration forms. Indeed, after oral administration, V2G is largely in majority followed by V3G, and some traces of V1G and V4G (data not shown). Sulfated metabolites, in low amounts in the in vivo study after intraperitoneal administration [33], were not found in this study.

In the only study on the bioavailability of $\varepsilon$ Vin in rodents, the authors measured its pharmacokinetic parameters, without measuring those of the metabolites. Authors used an oral administration of $40 \mathrm{mg} / \mathrm{kg}$ bw, which is two times higher than the amount we used in our study $(20 \mathrm{mg} / \mathrm{kg} \mathrm{bw})$. They obtained a $\mathrm{C}_{\max }$ and an $\mathrm{AUC}_{0-\infty}, 2.8$ and 3.6 times higher than our values, respectively. All these results confirm that $\varepsilon$ Vin is absorbed after oral administration and that its plasma concentration increases with the quantity administrated [31]. The pharmacokinetic analysis of free $\varepsilon$ Vin in plasma revealed a strong glucuronidation of $\varepsilon$ Vin after oral administration of $20 \mathrm{mg} / \mathrm{kg}$ bw of the native form. Indeed, the maximal concentration of glucuronide forms is more than 100 times higher than the concentration of native form. After intraperitoneal administration of $50 \mathrm{mg} / \mathrm{kg}$ bw of $\varepsilon$ Vin, Courtois et al. demonstrated that glucuronides were only 1.2 times more concentrated in plasma than the native form [33]. Although in the latter study $\varepsilon V G$ was expressed in $\varepsilon$ Vin equivalents, underestimating the glucuronide concentration by about 8 -fold, it is shown here that $\varepsilon$ Vin undergoes much greater glucuronidation when administered orally than intraperitoneally. This could be explained by an intense intestinal metabolism of $\varepsilon$ Vin, as it has been already demonstrated for resveratrol $[60,61]$. Concerning these glucuronides, the two peaks on the kinetic of their plasma concentrations, at 20 and $100 \mathrm{~min}$, could match with an enterohepatic recirculation of these metabolites. This enterohepatic cycle has already been demonstrated for glucuronic metabolites of other polyphenols, such as quercetin [62], but never for metabolites of stilbenes to our knowledge. However, different studies on stilbenes have shown that the second absorption peak of the native form occurs at different times depending on the molecule, the doses and the animal model used. This second absorption peak appeared around $60 \mathrm{~min}$ after oral administration of pterostilbene [63] and resveratrol $[64,65]$ or more than $10 \mathrm{~h}$ for the trimer, $\alpha$-viniferine [66], for example. Supplemental experiments such as bile analysis could confirm this hypothesis and determine in what form the molecule undergoes this enterohepatic circulation $[67,68]$. 
The impact of $\varepsilon$ Vin encapsulation in MLLs on plasma $\varepsilon V G$ concentrations (appearance of a plateau) could be explained by a sustained release of $\varepsilon$ Vin from the MLLs in the lumen of the digestive tract. Indeed, the MLLs could be gradually degraded during the different digestion stages and more particularly in the lumen of the digestive tract, thus increasing the duration of exposure of $\varepsilon$ Vin to the intestinal wall. Very few studies reported the use of encapsulated active compounds with MLLs for an oral administration in vivo in rats or other laboratory animals. However, Freund et al. (2001) reported that, after oral administration, encapsulation of ${ }^{111}$ In-NTA (labeled amino-polycarboxylic acid) in spherulites led to a greater stability of the compound into the different gastrointestinal levels compared to the free form of the same compound [69]. Moreover, it was reported that MLLs' encapsulation of ${ }^{111}$ In-NTA significantly increases its plasma concentration in rats [70]. These authors suggested that the encapsulation process is able to increase the bioavailability of compound. In our study, encapsulation does not modify the plasma concentrations of the native molecule ( $\varepsilon$ Vin) but shows a tendency to increase that of the metabolites $(\varepsilon V G)$.

In addition, the Lambda-z, i.e., the terminal elimination rate constant, is significantly smaller for $\varepsilon V G$ when $\varepsilon$ Vin has been administrated under its encapsulated form, which is correlated with the increase in the $T_{1 / 2}$ of the compound in plasma. The significant variations of these two parameters, a trend of increase in the $\mathrm{AUC}_{0-\infty}$, as well as the significant increase of $\varepsilon V G$ concentrations in plasma, liver and kidneys at $4 \mathrm{~h}$ suggest a slower elimination and thus a longer exposure time of $\varepsilon V G$ in the organism. The use of the encapsulated form could therefore result in a better and prolonged biological efficacy of the glucuronide compounds. Indeed, it is suggested today that glucuronide compounds have biological properties [71]; for example, it has recently been shown that resveratrol and pterostilbene are able to reduce steatosis in cultured hepatocytes [72,73].

According to tissue analysis, $\varepsilon$ Vin was found in higher concentrations in white adipose tissues than in plasma, liver and kidneys $4 \mathrm{~h}$ after oral administration. This important presence of the native form in white adipose tissues had already been demonstrated after intraperitoneal administration [33]. However, this is the first time that it has been shown that, although it is extensively metabolized, a stilbene is stored in relatively large quantities in its native form in white adipose tissues after oral administration. The native form being more lipophilic than the glucuronide ones might suggest that they are stored in the unilocular lipid droplets in adipocytes. Adipose tissues could thus act as a reservoir for $\varepsilon$ Vin after having captured the native circulating form, or after the cleavage of the glucuronide group of the metabolites. Unlike the intraperitoneal study, the glucuronide forms are also found in adipose tissues, testifying to the strong intestinal metabolism after oral administration.

Interestingly, the $\varepsilon$ Vin and $\varepsilon V G$ contents were higher in the mesenteric depot than in the three other ones (except for $\varepsilon V G$ in the subcutaneous one), the encapsulation of $\varepsilon$ Vin significantly increasing the accumulation of the glucuronide metabolites in this adipose tissue. Mesenteric adipose tissue, dispersed throughout the small intestine, is highly vascularized with a great metabolic activity in the post-prandial state [74]. Thus, if these anatomical and functional differences could logically explain the increased amount of $\varepsilon$ Vin and $\varepsilon V G$, we also do not rule out possible plasma contamination of the tissues during their sampling. However, the hypothesis of proximity to the digestive system or of contamination with the plasma cannot justify the relatively high concentrations found in the subcutaneous fatty tissues, again suggesting a storage role of adipose tissues.

\section{Conclusions}

Our study showed significant glucuronidation of $\varepsilon$ Vin which occurred mainly in the liver and probably also in the intestine after oral administration. The presence of $\varepsilon$ Vin and its glucuronide metabolites in adipose tissues was also demonstrated, which means that adipose tissues could represent a storage tissue, but also be a target tissue in which the dimer could regulate lipid metabolism. 
This study also showed that, although encapsulation did not improve the plasma concentrations of $\varepsilon$ Vin, its main impact was to prolong the exposure of organism to its glucuronide metabolites. Therefore, now that the encapsulation protocol has been developed, it could be used to study the promising biological application of $\varepsilon$ Vin for human health.

Author Contributions: Conceptualization, A.C., P.B., S.K., C.A., C.F., M.J., T.R.; methodology, P.B., A.C., M.J., A.M., C.F., T.R., C.A., S.K.; method validation, P.B., A.M.; formal analysis, A.C., S.K., C.A., P.B., A.M., M.J.; investigation, A.C., S.K., C.A., P.B., C.F., M.J.; data curation, P.B., A.M.; funding acquisition: A.C., S.K., C.A., C.F., P.-L.T., T.R.; writing—original draft preparation, P.B., A.C., S.K., C.A.; writing-review and editing, P.B., A.C., M.J., A.M., C.F., T.R., C.A., S.K.; supervision, C.A., A.C., S.K., C.F., T.R. All authors have read and agreed to the published version of the manuscript.

Funding: This work was supported by Bordeaux Metabolome Facility and MetaboHUB (ANR-11INBS-0010 project).

Institutional Review Board Statement: The study was conducted according to the Directive 2010/63/EU, and approved by the Bordeaux University Institutional Ethics Committee for Animal Research (IECAR CEEA 50, MESR approval A18380).

Informed Consent Statement: Informed consent was obtained from all subjects involved in the study.

Data Availability Statement: The data presented in this study are available upon request from the corresponding author.

Acknowledgments: The authors thank the QIV axis from the Enology Research Unit (EA 4577, USC 1366 INRAE, ISVV, Université de Bordeaux), especially Marie Le Scanff.

Conflicts of Interest: The authors declare no conflict of interest.

\section{References}

1. Lin, M.; Yao, C.S. Natural oligostilbenes. In Studies in Natural Products Chemistry; Elsevier: Amsterdam, The Netherlands, 2006; Volume 33, pp. 601-644.

2. Pugajeva, I.; Perkons, I.; Górnaś, P. Identification and Determination of Stilbenes by Q-TOF in Grape Skins, Seeds, Juice and Stems. J. Food Compos. Anal. 2018, 74, 44-52. [CrossRef]

3. El Khawand, T.; Courtois, A.; Valls, J.; Richard, T.; Krisa, S. A Review of Dietary Stilbenes: Sources and Bioavailability. Phytochem. Rev. 2018, 17, 1007-1029. [CrossRef]

4. Vitrac, X.; Bornet, A.; Vanderlinde, R.; Valls, J.; Richard, T.; Delaunay, J.C.; Mérillon, J.M.; Teissédre, P.L. Determination of Stilbenes ( $\delta$-Viniferin, Trans-Astringin, Trans-Piceid, Cis- and Trans-Resveratrol, $\varepsilon$-Viniferin) in Brazilian Wines. J. Agric. Food Chem. 2005, 53, 5664-5669. [CrossRef]

5. Zamora-Ros, R.; Andres-Lacueva, C.; Lamuela-Raventós, R.M.; Berenguer, T.; Jakszyn, P.; Martínez, C.; Sánchez, M.J.; Navarro, C.; Chirlaque, M.D.; Tormo, M.-J.; et al. Concentrations of Resveratrol and Derivatives in Foods and Estimation of Dietary Intake in a Spanish Population: European Prospective Investigation into Cancer and Nutrition (EPIC)-Spain Cohort. Br. J. Nutr. 2008, 100, 188-196. [CrossRef]

6. Li, G.; Zhu, Y.; Zhang, Y.; Lang, J.; Chen, Y.; Ling, W. Estimated Daily Flavonoid and Stilbene Intake from Fruits, Vegetables, and Nuts and Associations with Lipid Profiles in Chinese Adults. J. Acad. Nutr. Diet. 2013, 113, 786-794. [CrossRef]

7. Benbouguerra, N.; Hornedo-Ortega, R.; Garcia, F.; el Khawand, T.; Saucier, C.; Richard, T. Stilbenes in Grape Berries and Wine and Their Potential Role as Anti-Obesity Agents: A Review. Trends Food Sci. Technol. 2021, 112, 362-381. [CrossRef]

8. Gabaston, J.; Leborgne, C.; Waffo-Teguo, P.; Valls, J.; Palos Pinto, A.; Richard, T.; Cluzet, S.; Mérillon, J.M. Wood and Roots of Major Grapevine Cultivars and Rootstocks: A Comparative Analysis of Stilbenes by UHPLC-DAD-MS/MS and NMR. Phytochem. Anal. 2019, 30, 320-331. [CrossRef]

9. Sáez, V.; Pastene, E.; Vergara, C.; Mardones, C.; Hermosín-Gutiérrez, I.; Gómez-Alonso, S.; Gómez, M.V.; Theoduloz, C.; Riquelme, S.; von Baer, D. Oligostilbenoids in Vitis vinifera L. Pinot Noir Grape Cane Extract: Isolation, Characterization, in Vitro Antioxidant Capacity and Anti-Proliferative Effect on Cancer Cells. Food Chem. 2018, 265, 101-110. [CrossRef]

10. Nopo-Olazabal, C.; Hubstenberger, J.; Nopo-Olazabal, L.; Medina-Bolivar, F. Antioxidant Activity of Selected Stilbenoids and Their Bioproduction in Hairy Root Cultures of Muscadine Grape (Vitis rotundifolia Michx.). J. Agric. Food Chem. 2013, 61, 11744-11758. [CrossRef]

11. Privat, C.; Telo, J.P.; Bernardes-Genisson, V.; Vieira, A.; Souchard, J.P.; Nepveu, F. Antioxidant Properties of Trans- $\varepsilon$-Viniferin as Compared to Stilbene Derivatives in Aqueous and Nonaqueous Media. J. Agric. Food Chem. 2002, 50, 1213-1217. [CrossRef]

12. Nassra, M.; Krisa, S.; Papastamoulis, Y.; Kapche, G.D.; Bisson, J.; André, C.; Konsman, J.P.; Schmitter, J.M.; Mérillon, J.M.; WaffoTéguo, P. Inhibitory Activity of Plant Stilbenoids against Nitric Oxide Production by Lipopolysaccharide-Activated Microglia. Planta Med. 2013, 79, 966-970. [CrossRef] [PubMed] 
13. Aja-Perez, I.; Krisa, S.; Hornedo-Ortega, R.; Ruiz-Larrea, M.B.; Ruiz-Sanz, J.I.; Richard, T.; Courtois, A. Stilbenes at Low Micromolar Concentrations Mitigate the NO, TNF- $\alpha$, IL-1 $\beta$ and ROS Production in LPS-Stimulated Murine Macrophages. J. Biol. Act. Prod. Nat. 2021, 11, 212-222. [CrossRef]

14. Rivière, C.; Papastamoulis, Y.; Fortin, P.Y.; Delchier, N.; Andriamanarivo, S.; Waffo-Teguo, P.; Kapche, G.D.W.F.; Amira-Guebalia, H.; Delaunay, J.C.; Mérillon, J.M.; et al. New Stilbene Dimers against Amyloid Fibril Formation. Bioorg. Med. Chem. Lett. 2010, 20, 3441-3443. [CrossRef] [PubMed]

15. Vion, E.; Page, G.; Bourdeaud, E.; Paccalin, M.; Guillard, J.; Rioux Bilan, A. Trans $\varepsilon$-Viniferin Is an Amyloid- $\beta$ Disaggregating and Anti-Inflammatory Drug in a Mouse Primary Cellular Model of Alzheimer's Disease. Mol. Cell. Neurosci. 2018, 88, 1-6. [CrossRef]

16. Fu, J.; Jin, J.; Cichewicz, R.H.; Hageman, S.A.; Ellis, T.K.; Xiang, L.; Peng, Q.; Jiang, M.; Arbez, N.; Hotaling, K.; et al. Trans-(-)$\varepsilon$-Viniferin Increases Mitochondrial Sirtuin 3 (SIRT3), Activates AMP-Activated Protein Kinase (AMPK), and Protects Cells in Models of Huntington Disease. J. Biol. Chem. 2012, 287, 24460-24472. [CrossRef]

17. Billard, C.; Izard, J.C.; Roman, V.; Kern, C.; Mathiot, C.; Mentz, F.; Kolb, J.P. Comparative Antiproliferative and Apoptotic Effects of Resveratrol, $\varepsilon$-Viniferin and Vine-Shots Derived Polyphenols (Vineatrols) on Chronic B Lymphocytic Leukemia Cells and Normal Human Lymphocytes. Leuk. Lymphoma 2002, 43, 1991-2002. [CrossRef]

18. Colin, D.; Lancon, A.; Delmas, D.; Lizard, G.; Abrossinow, J.; Kahn, E.; Jannin, B.; Latruffe, N. Antiproliferative Activities of Resveratrol and Related Compounds in Human Hepatocyte Derived HepG2 Cells Are Associated with Biochemical Cell Disturbance Revealed by Fluorescence Analyses. Biochimie 2008, 90, 1674-1684. [CrossRef]

19. Barjot, C.; Tournaire, M.; Castagnino, C.; Vigor, C.; Vercauteren, J.; Rossi, J.F. Evaluation of Antitumor Effects of Two Vine Stalk Oligomers of Resveratrol on a Panel of Lymphoid and Myeloid Cell Lines: Comparison with Resveratrol. Life Sci. 2007, 81, 1565-1574. [CrossRef]

20. Nivelle, L.; Aires, V.; Rioult, D.; Martiny, L.; Tarpin, M.; Delmas, D. Molecular Analysis of Differential Antiproliferative Activity of Resveratrol, Epsilon Viniferin and Labruscol on Melanoma Cells and Normal Dermal Cells. Food Chem. Toxicol. 2018, 116, 323-334. [CrossRef]

21. Özdemir, F.; İncesu, Z.; Şena, M.; Öndera, N.İ; Dikme, M. Implications of Enhanced Effectiveness of Vincristine Sulfate/ $\varepsilon$-Viniferin Combination Compared to Vincristine Sulfate Only on HepG2 Cells. Dicle Tip Derg. 2016, 43, 534-541.

22. Özdemir, F.; Apaydın, E.; Önder, N.İ.; Şen, M.; Ayrım, A.; Öğünç, Y.; İncesu, Z. Apoptotic Effects of $\varepsilon$-Viniferin in Combination with Cis-Platin in C6 Cells. Cytotechnology 2018, 70, 1061-1073. [CrossRef] [PubMed]

23. Ha, D.T.; Chen, Q.C.; Hung, T.M.; Youn, U.J.; Ngoc, T.M.; Thuong, P.T.; Kim, H.J.; Seong, Y.H.; Min, B.S.; Bae, K. Stilbenes and Oligostilbenes from Leaf and Stem of Vitis Amurensis and Their Cytotoxic Activity. Arch. Pharmacal. Res. 2009, 32, 177-183. [CrossRef] [PubMed]

24. Marel, A.K.; Lizard, G.; Izard, J.C.; Latruffe, N.; Delmas, D. Inhibitory Effects of Trans-Resveratrol Analogs Molecules on the Proliferation and the Cell Cycle Progression of Human Colon Tumoral Cells. Mol. Nutr. Food Res. 2008, 52, 538-548. [CrossRef] [PubMed]

25. Lee, S.; Mailar, K.; il Kim, M.; Park, M.; Kim, J.; Min, D.H.; Heo, T.H.; Bae, S.K.; Choi, W.; Lee, C. Plant-Derived Purification, Chemical Synthesis, and in Vitro/in Vivo Evaluation of a Resveratrol Dimer, Viniferin, as an HCV Replication Inhibitor. Viruses 2019, 11, 890. [CrossRef] [PubMed]

26. Yáñez, M.; Fraiz, N.; Cano, E.; Orallo, F. (-)-Trans- $\varepsilon$-Viniferin, a Polyphenol Present in Wines, Is an Inhibitor of Noradrenaline and 5-Hydroxytryptamine Uptake and of Monoamine Oxidase Activity. Eur. J. Pharmacol. 2006, 542, 54-60. [CrossRef]

27. Zghonda, N.; Yoshida, S.; Araki, M.; Kusunoki, M.; Mliki, A.; Ghorbel, A.; Miyazaki, H. Greater Effectiveness of $\varepsilon$-Viniferin in Red Wine than Its Monomer Resveratrol for Inhibiting Vascular Smooth Muscle Cell Proliferation and Migration. Biosci. Biotechnol. Biochem. 2011, 75, 1259-1267. [CrossRef]

28. Zghonda, N.; Yoshida, S.; Ezaki, S.; Otake, Y.; Murakami, C.; Mliki, A.; Ghorbel, A.; Miyazaki, H. $\varepsilon$-Viniferin Is More Effective than Its Monomer Resveratrol in Improving the Functions of Vascular Endothelial Cells and the Heart. Biosci. Biotechnol. Biochem. 2012, 76, 954-960. [CrossRef] [PubMed]

29. Ohara, K.; Kusano, K.; Kitao, S.; Yanai, T.; Takata, R.; Kanauchi, O. $\varepsilon$-Viniferin, a Resveratrol Dimer, Prevents Diet-Induced Obesity in Mice. Biochem. Biophys. Res. Commun. 2015, 468, 877-882. [CrossRef] [PubMed]

30. Lu, Y.L.; Lin, S.Y.; Fang, S.U.; Hsieh, Y.Y.; Chen, C.R.; Wen, C.L.; Chang, C.I.; Hou, W.C. Hot-Water Extracts from Roots of Vitis thunbergii Var. Taiwaniana and Identified $\sigma$-Viniferin Improve Obesity in High-Fat Diet-Induced Mice. J. Agric. Food Chem. 2017, 65, 2521-2529. [CrossRef]

31. Kim, J.; Min, J.S.; Kim, D.; Zheng, Y.F.; Mailar, K.; Choi, W.J.; Lee, C.; Bae, S.K. A Simple and Sensitive Liquid ChromatographyTandem Mass Spectrometry Method for Trans- $\varepsilon$-Viniferin Quantification in Mouse Plasma and Its Application to a Pharmacokinetic Study in Mice. J. Pharm. Biomed. Anal. 2017, 134, 116-121. [CrossRef]

32. Willenberg, I.; Michael, M.; Wonik, J.; Bartel, L.C.; Empl, M.T.; Schebb, N.H. Investigation of the Absorption of Resveratrol Oligomers in the Caco-2 Cellular Model of Intestinal Absorption. Food Chem. 2015, 167, 245-250. [CrossRef] [PubMed]

33. Courtois, A.; Atgié, C.; Marchal, A.; Hornedo-Ortega, R.; Lapèze, C.; Faure, C.; Richard, T.; Krisa, S. Tissular Distribution and Metabolism of Trans- $\varepsilon$-Viniferin after Intraperitoneal Injection in Rat. Nutrients 2018, 10, 1660. [CrossRef]

34. Mao, P.; Lei, Y.; Zhang, T.; Ma, C.; Jin, B.; Li, T. Pharmacokinetics, Bioavailability, Metabolism and Excretion of $\delta$-Viniferin in Rats. Acta Pharm. Sin. B 2016, 6, 243-252. [CrossRef] [PubMed] 
35. Lewandowska, U.; Szewczyk, K.; Hrabec, E.; Janecka, A.; Gorlach, S. Overview of Metabolism and Bioavailability Enhancement of Polyphenols. J. Agric. Food Chem. 2013, 61, 12183-12199. [CrossRef] [PubMed]

36. Davidov-Pardo, G.; McClements, D.J. Resveratrol Encapsulation: Designing Delivery Systems to Overcome Solubility, Stability and Bioavailability Issues. Trends Food Sci. Technol. 2014, 38, 88-103. [CrossRef]

37. Lu, W.; Kelly, A.L.; Miao, S. Emulsion-Based Encapsulation and Delivery Systems for Polyphenols. Trends Food Sci. Technol. 2016, 47, 1-9. [CrossRef]

38. Ozkan, G.; Kostka, T.; Esatbeyoglu, T.; Capanoglu, E. Effects of Lipid-Based Encapsulation on the Bioaccessibility and Bioavailability of Phenolic Compounds. Molecules 2020, 25, 5545. [CrossRef]

39. Rahim, R.A.; Jayusman, P.A.; Muhammad, N.; Ahmad, F.; Mokhtar, N.; Mohamed, I.N.; Mohamed, N.; Shuid, A.N. Recent Advances in Nanoencapsulation Systems Using Plga of Bioactive Phenolics for Protection against Chronic Diseases. Int. J. Environ. Res. Public Health 2019, 16, 4962. [CrossRef]

40. Augustin, M.A.; Abeywardena, M.Y.; Patten, G.; Head, R.; Lockett, T.; de Luca, A.; Sanguansri, L. Effects of Microencapsulation on the Gastrointestinal Transit and Tissue Distribution of a Bioactive Mixture of Fish Oil, Tributyrin and Resveratrol. J. Funct. Foods 2011, 3, 25-37. [CrossRef]

41. Pandita, D.; Kumar, S.; Poonia, N.; Lather, V. Solid Lipid Nanoparticles Enhance Oral Bioavailability of Resveratrol, a Natural Polyphenol. Food Res. Int. 2014, 62, 1165-1174. [CrossRef]

42. Shaikh, J.; Ankola, D.D.; Beniwal, V.; Singh, D.; Kumar, M.N.V.R. Nanoparticle Encapsulation Improves Oral Bioavailability of Curcumin by at Least 9-Fold When Compared to Curcumin Administered with Piperine as Absorption Enhancer. Eur. J. Pharm. Sci. 2009, 37, 223-230. [CrossRef] [PubMed]

43. Dian, L.; Yu, E.; Chen, X.; Wen, X.; Zhang, Z.; Qin, L.; Wang, Q.; Li, G.; Wu, C. Enhancing Oral Bioavailability of Quercetin Using Novel Soluplus Polymeric Micelles. Nanoscale Res. Lett. 2014, 9, 1-11. [CrossRef] [PubMed]

44. Coimbra, M.; Isacchi, B.; van Bloois, L.; Torano, J.S.; Ket, A.; Wu, X.; Broere, F.; Metselaar, J.M.; Rijcken, C.J.F.; Storm, G.; et al. Improving Solubility and Chemical Stability of Natural Compounds for Medicinal Use by Incorporation into Liposomes. Int. J. Pharm. 2011, 416, 433-442. [CrossRef]

45. Courtois, A.; Garcia, M.; Krisa, S.; Atgié, C.; Sauvant, P.; Richard, T.; Faure, C. Encapsulation of $\epsilon$-Viniferin in Onion-Type Multi-Lamellar Liposomes Increases Its Solubility and Its Photo-Stability and Decreases Its Cytotoxicity on Caco-2 Intestinal Cells. Food Funct. 2019, 10, 2573-2582. [CrossRef] [PubMed]

46. Pimentel-Moral, S.; Teixeira, M.C.; Fernandes, A.R.; Arráez-Román, D.; Martínez-Férez, A.; Segura-Carretero, A.; Souto, E.B. Lipid Nanocarriers for the Loading of Polyphenols-A Comprehensive Review. Adv. Colloid Interface Sci. 2018, 260, 85-94. [CrossRef] [PubMed]

47. Huang, M.; Su, E.; Zheng, F.; Tan, C. Encapsulation of Flavonoids in Liposomal Delivery Systems: The Case of Quercetin, Kaempferol and Luteolin. Food Funct. 2017, 8, 3198-3208. [CrossRef]

48. Beaumont, P.; Courtois, A.; Richard, T.; Krisa, S.; Faure, C. Encapsulation of $\varepsilon$-Viniferin into Multi-Lamellar Liposomes: Development of a Rapid, Easy and Cost-Efficient Separation Method to Determine the Encapsulation Efficiency. Pharmaceutics 2021, 13, 566. [CrossRef]

49. Biais, B.; Krisa, S.; Cluzet, S.; da Costa, G.; Waffo-Teguo, P.; Mérillon, J.M.; Richard, T. Antioxidant and Cytoprotective Activities of Grapevine Stilbenes. J. Agric. Food Chem. 2017, 65, 4952-4960. [CrossRef]

50. Courtois, A.; Jourdes, M.; Dupin, A.; Lapèze, C.; Renouf, E.; Biais, B.; Teissedre, P.L.; Mérillon, J.M.; Richard, T.; Krisa, S. In Vitro Glucuronidation and Sulfation of $\epsilon$-Viniferin, a Resveratrol Dimer, in Humans and Rats. Molecules 2017, 22, 733. [CrossRef]

51. Directive 2010/63/Eu of the European Parliament and of the Council of 22 September 2010 on the Protection of Animals Used for Scientific Purposes (Text with EEA Relevance). Available online: https://norecopa.no/legislation/eu-directive-201063 (accessed on 1 October 2021).

52. FDA. Bioanalytical Method Validation Guidance for Industry Biopharmaceutics Bioanalytical Method Validation Guidance for Industry Biopharmaceutics Contains Nonbinding Recommendations; Food and Drug Administration: Rockville, MD, USA, 2018.

53. European Medicines Agency. 2** Committee for Medicinal Products for Human Use (CHMP) Guideline on Bioanalytical Method Validation; European Medicines Agency: Amsterdam, The Netherlands, 1922.

54. Liu, Q.; Liao, X.; Xu, J.; Zhao, J.; Luo, J.; Kong, L. Development and Validation of a Sensitive and Selective LC-MS/MS Method for the Determination of Trans $\delta$-Veniferin, a Resveratrol Dehydrodimer, in Rat Plasma and Its Application to Pharmacokinetics and Bioavailability Studies. J. Chromatogr. B Anal. Technol. Biomed. Life Sci. 2014, 958, 124-129. [CrossRef]

55. Li, S.; Xie, X.; Li, D.; Yu, Z.; Tong, L.; Zhao, Y. Simultaneous Determination and Tissue Distribution Studies of Four Phenolic Acids in Rat Tissue by UFLC-MS/MS after Intravenous Administration of Salvianolic Acid for Injection. Biomed. Chromatogr. 2018, 32, e4128. [CrossRef]

56. Su, M.X.; Di, B.; Hang, T.J.; Wang, J.; Yang, D.S.; Wang, T.H.; Meng, R. Rapid, Sensitive and Selective Analysis of Trans-Resveratrol in Rat Plasma by LC-MS-MS. Chromatographia 2011, 73, 1203-1210. [CrossRef]

57. Chen, L.; Weng, Q.; Ma, J. A New UPLC-MS/MS Method Validated for Quantification of Jervine in Rat Plasma and the Study of Its Pharmacokinetics in Rats. J. Anal. Methods Chem. 2019, 2019, 5163625. [CrossRef] [PubMed]

58. Alam, M.A.; Al-Jenoobi, F.I.; Al-Mohizea, A.M. Rapid, Validated UPLC-MS/MS Method for Determination of Glibenclamide in Rat Plasma. Int. J. Anal. Chem. 2018, 2018, 2569027. [CrossRef] [PubMed] 
59. De Baere, S.; Croubels, S.; Novak, B.; Bichl, G.; Antonissen, G. Development and Validation of a UPLC-MS/MS and UPLC-HR-MS Method for the Determination of Fumonisin B1 and Its Hydrolysed Metabolites and Fumonisin B2 in Broiler Chicken Plasma. Toxins 2018, 10, 62. [CrossRef]

60. Jarosova, V.; Vesely, O.; Doskocil, I.; Tomisova, K.; Marsik, P.; Jaimes, J.D.; Smejkal, K.; Kloucek, P.; Havlik, J. Metabolism of Cisand Trans-Resveratrol and Dihydroresveratrol in an Intestinal Epithelial Model. Nutrients 2020, 12, 595. [CrossRef] [PubMed]

61. Zhang, B.; Xu, Y.; Lv, H.; Pang, W.; Wang, J.; Ma, H.; Wang, S. Intestinal Pharmacokinetics of Resveratrol and Regulatory Effects of Resveratrol Metabolites on Gut Barrier and Gut Microbiota. Food Chem. 2021, 357, 129532. [CrossRef] [PubMed]

62. Yang, L.-L.; Xiao, N.; Li, X.-W.; Fan, Y.; Alolga, R.N.; Sun, X.-Y.; Wang, S.-L.; Li, P.; Qi, W. Pharmacokinetic Comparison between Quercetin and Quercetin 3-O- $\beta$-Glucuronide in Rats by UHPLC-MS/MS OPEN. Nat. Publ. Group 2016, 6, 1-9. [CrossRef]

63. Deng, L.; Li, Y.; Zhang, X.; Chen, B.; Deng, Y.; Li, Y. UPLC-MS Method for Quantification of Pterostilbene and Its Application to Comparative Study of Bioavailability and Tissue Distribution in Normal and Lewis Lung Carcinoma Bearing Mice. J. Pharm. Biomed. Anal. 2015, 114, 200-207. [CrossRef]

64. Almeida, L.; Vaz-da-Silva, M.; Falcão, A.; Soares, E.; Costa, R.; Loureiro, A.I.; Fernandes-Lopes, C.; Rocha, J.F.; Nunes, T.; Wright, L.; et al. Pharmacokinetic and Safety Profile of Trans-Resveratrol in a Rising Multiple-Dose Study in Healthy Volunteers. Mol. Nutr. Food Res. 2009, 53, S7-S15. [CrossRef]

65. Kapetanovic, I.M.; Muzzio, M.; Huang, Z.; Thompson, T.N.; McCormick, D.L. Pharmacokinetics, Oral Bioavailability, and Metabolic Profile of Resveratrol and Its Dimethylether Analog, Pterostilbene, in Rats. Cancer Chemother. Pharmacol. 2011, 68, 593. [CrossRef]

66. Fan, Y.; Zhao, L.; Huang, X.; Jia, Q.; Wang, W.; Gao, M.; Jia, X.; Chang, Y.; Ouyang, H.; He, J. Pharmacokinetic and Bioavailability Studies of $\alpha$-Viniferin after Intravenous and Oral Administration to Rats. J. Pharm. Biomed. Anal. 2020, 188, 113376. [CrossRef]

67. Hofmann, A.F. Overview: Enterohepatic Circulation of Bile Acids-A Topic in Molecular Physiology. Bile Acids Health Dis. 1988, 1-18. [CrossRef]

68. Zhou, X.; Cassidy, K.C.; Hudson, L.; Mohutsky, M.A.; Sawada, G.A.; Hao, J. Enterohepatic Circulation of Glucuronide Metabolites of Drugs in Dog. Pharmacol. Res. Perspect. 2019, 7, 502. [CrossRef]

69. Freund, O. Biodistribution and Gastrointestinal Drug Delivery of New Lipidic Multilamellar Vesicles. Drug Deliv. 2001, 8, 239-244. [CrossRef]

70. Freund, O.; Amédee, J.; Roux, D.; Laversanne, R. In Vitro and in Vivo Stability of New Multilamellar Vesicles. Life Sci. 2000, 67, 411-419. [CrossRef]

71. Luca, S.V.; Macovei, I.; Bujor, A.; Miron, A.; Skalicka-Woźniak, K.; Aprotosoaie, A.C.; Trifan, A. Bioactivity of Dietary Polyphenols: The Role of Metabolites. Crit. Rev. Food Sci. Nutr. 2020, 60, 626-659. [CrossRef] [PubMed]

72. Trepiana, J.; Krisa, S.; Portillo, M.P. Activity of Pterostilbene Metabolites against Liver Steatosis in Cultured Hepatocytes. Molecules 2020, 25, 5444. [CrossRef] [PubMed]

73. Trepiana, J.; Krisa, S.; Renouf, E.; Portillo, M.P. Resveratrol Metabolites Are Able to Reduce Steatosis in Cultured Hepatocytes. Pharmaceuticals 2020, 13, 285. [CrossRef]

74. Ibrahim, M.M. Subcutaneous and Visceral Adipose Tissue: Structural and Functional Differences. Obes. Metab. 2010, 7, 64-65. [CrossRef] 